\title{
Water Quality Analysis on Tertiary Channels Using Macroinvertebrate In Songka Sub-District, Palopo City
}

\author{
Abdul Rais ${ }^{1}$, Aminudin Afandhi², Budi Prasetya ${ }^{3}$ \\ ${ }_{1}^{1}$ post Graduate School of Environmental and Development, Graduate Program, Brawijaya University, Malang, Indonesia \\ ${ }^{2}$ Pest and Plant Disease Departement, Faculty of Agriculture, Brawijaya University, Malang, Indonesia \\ ${ }^{3}$ Agriculture Department, Faculty of Agriculture, Brawijaya University, Malang, Indonesia
}

\begin{abstract}
Changes in the condition of aquatic environment are now a major problem for the survival of every organism caused by changes in land use, human activities, and agriculture. This study aims to determine the structure of macroinvertebrate communities. In addition, this study also aims to conduct analysis on BMWP index and water quality testing using physical and chemical parameters. This study was conducted on tertiary channels in Songka Sub-District, Palopo City. Each station's data collection covered relative density, macroinvertebrates that were found were assessed using BMWP index, then they were calculated using ASPT index. The results of this study found 17 taxa classified in the class of gastropods, insecta, bivalvia, malacostraca, citellata, oligochaeta and hirudenia. The results of BMWP index modification analysis from all stations found that ASPT value was "quite-poor" and "bad". It was indicated that in each station was mainly dominated by Oligochaeta worms and tolerant macroinvertebrates. Testing of physical and chemical parameters obtained DO value which belonged to class II of water quality. The low DO value caused high BOD value, which was classified in class III. The high value of BOD had an effect on the rise of COD value, the increase of COD value was caused by the high amount of organic and inorganic materials entering the water. $\mathrm{PH}$ value was relatively normal with the range of 6.3 to 6.8 , temperature was in the range of $27.1^{\circ} \mathrm{C}$ to $28^{\circ} \mathrm{C}$, the rise in temperature value was influenced by tree shade and the intensity of sunlight.
\end{abstract}

Keywords: BMWP-ASPT, Community structure, Macroinvertebrate, Pollution, Tertiary channel,

\section{INTRODUCTION}

Water is one of the natural resources needed by living creatures. A water quality expert from the University of Birmingham believes that water is a very important natural resource in the world. If there was no water, then life would never exist and most industries would not operate [1].

[2] Government Regulation (PP) No. 121 Year 2015 on the Utilization of Water Resources explains that water is all water contained above or below the soil surface, including sea water on land. Good water quality will dictate wider use, since water quality is the quality of water that meets the standards for a predetermined purpose [3].

Water quality determines the viability of water biota and human that directly utilize the water. The utilization include: for bathing, washing and defecation, and for the disposal of livestock waste, agricultural waste, and household waste. All of those activities can cause water pollution that can affect

\footnotetext{
Correspondence address:

Abdul Rais

Email : abdulrais021@gmail.com

Address : Graduate Program of Environmental Resources Management and Development, Brawijaya University
}

water quality status. [4] Water contamination is the inclusion of organic or inorganic materials or other components into water so that it can affect the decrease of water quality.

Changes in aquatic ecosystems caused by the expansion of agricultural land and the increase in irregular human activity have caused great concern about the availability and quality of water sources [5]. In this way, the ecological integrity of rivers has been a problem of water quality degradation to human interests worldwide. Good and bad water conditions were influenced by surrounding activities [6]. [7] Existing activities can degrade water quality, then it will disrupt the survival of water biota. The more to the downstream, the quality of water decreases due to the pollution of organic matter from human activities [8]. Many ways are used to monitor water quality, either chemically, physically, or biologically [9].

The tertiary channel is a channel of irrigation channeled from the primary and secondary channels. There are water macroinvertebrates living in this channel. The tertiary channels in Palopo City have partially been using pelengsengan, so that it can affect the life cycle. Benthic macroinvertebrates are basically aquatic organisms that are relatively difficult to migrate and have high sensitivity due to 
water pollution, thus providing an illustration of physical, chemical and biological conditions [10]. Aquatic macroinvertebrates can be used as bioindicators, since they are easily found in most waters, have long life cycles, and they can show evidence of a condition over a long period of time [11].

Water quality and differences in physical and chemical parameters can affect the presence of macroinvertebrates [12]. The existence of macroinvertebrates greatly affect the water quality. Natural ecosystems in general will determine the stability of macroinvertebrates in the water, so the existence of macroinvertebrates in the rice field sector is no longer detrimental. In essence, the stability of ecosystems can be applied in order to suppress excessive use of pesticides to reduce pollution levels.

So far, problems with water quality have been a problem for macroinvertebrate survival. Biomonitoring can be used to determine water quality [13]. This study aims to determine the structure of macroinvertebrate communities. In addition, this study also aims to conduct an analysis on BMWP index and water quality testing using physical and chemical parameters in tertiary channels in Songka Selatan Sub-District of Palopo City.

\section{MATERIAL AND METHOD Data Collection}

The data needed in this research are primary and secondary data. Primary data is obtained from direct measurements in the field and in the laboratory. Primary data consists of macroinvertebrate communities, physical and chemical indicator testing. Secondary data is data obtained from literature studies covering several theories of BMWP-ASPT and Map of study sites.

Determination of station is determined based on the consideration of land use. Station 1 and 2 are determined based on conditions that are in production forest areas, rice fields and non-densely populated housing. Station 3 and 4 are located in rice fields, farms, and densely populated housing. Data is taken using modified macroinvertebrate nets.

Source of data in this research is the existence of macroinvertebrates. The data obtained is in the form of macroinvertebrate family as bioindicator of water quality, then it is calculated using relative density of macroinvertebrates. According to [14].
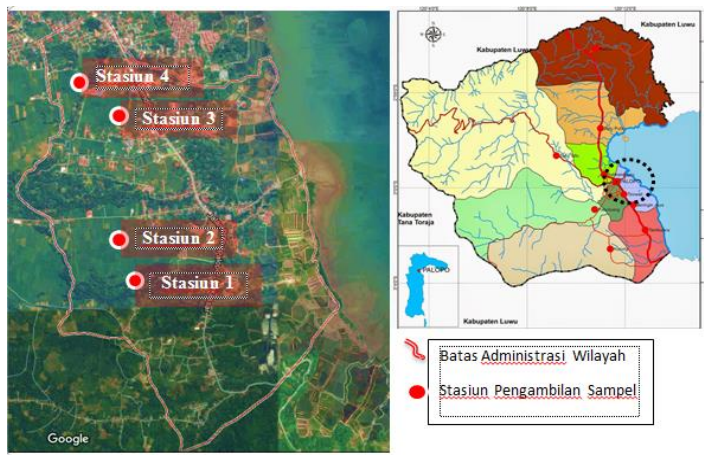

Fig 1. Area of Study

$$
\mathrm{KR}=\frac{\text { density of a family }}{\sum \text { density of families }} \times 100 \%
$$

The use of BMWP-ASPT Method. Then the measurement of physical and chemical parameters include temperature, pH, DO (Dissolved Oxygen), COD (Chemical Oxygen Demand), BOD (Biochemical Oxygen Demand). ASPT value category according to [15].

$$
\text { ASPT }=\frac{\text { total score of BMWP index }}{\sum \text { families found and has a BMWP index }}
$$

Table 1. ASPT category value

\begin{tabular}{c|c}
\hline ASPT Value & Water Quality \\
\hline$>6.0$ & Excellent \\
$5.5-6.0$ & Very good \\
$5.0-5.5$ & Good \\
$4.5-5.0$ & Quite bad \\
$4.0-4.5$ & Quite-poor \\
$<4.0$ & Bad \\
\hline
\end{tabular}

(Source: Galbrand et al., 2007).

\section{RESULTS AND DISCUSSION \\ Macroinvertebrate Community}

The number of macroinvertebrate taxa richness found in tertiary channels of rice fields in Songka Sub-District were 17 families (Table 2). Taxa found was classified in 11 orders, included: Basommatophora, Architaenioglossa, Diptera, Ephemeroptera, Odonata, Coleoptera, Hemiptera, Unionida, Decapoda, Isopoda, and Rhynchobdellida. There were various taxa richness found in each station. Station 1 got the highest taxa number, i.e. 11 taxas, while station 2 and 3 got 9 taxas, and station 4 found the lowest taxa number, which was 7 taxas (Figure 2). 
Table 2. The Spread of Macroinvertebrate Community

\begin{tabular}{ccc}
\hline Order & Family & $\begin{array}{c}\text { Found in } \\
\text { Station }\end{array}$ \\
\hline Basomatophora & Physidae & $1,2,3,4$ \\
Architaenioglossa & Viviparidae & 1 \\
Diptera & Chironomidae & 1 \\
Ephemeropthera & Baetidae & 1,2 \\
Odonata & Coenagrionidae & 1 \\
Coleoptera & Gomhiidae & $1,2,3,4$ \\
& Hydrophiliidae & 1 \\
Hemiptera & Hydrometriidae & 1 \\
& Gerridae & 2 \\
Unionida & Belostomatidae & 1 \\
Decapoda & Unionidae & $2,3,4$ \\
Isopoda & Grapsidae & 2 \\
Rhynchobdellida & Atyidae & 3,4 \\
- & Scypacidae & 3 \\
- & Lumbiphoniidae & 3 \\
\hline
\end{tabular}

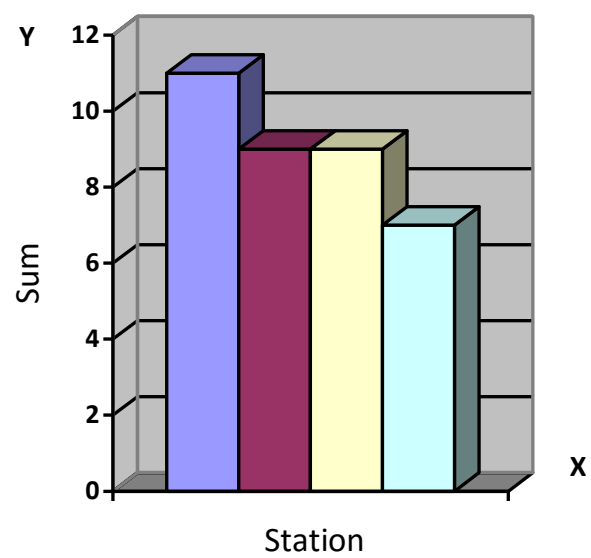

\begin{tabular}{|l|l|}
\hline$\square$ Station 1 & 11 \\
\hline$\square$ Station 2 & 9 \\
\hline$\square$ Station 3 & 9 \\
\hline$\square$ Station 4 & 7 \\
\hline
\end{tabular}

Figure 2. The Number of Macroinvertebrate Taxas

The highest number of taxa was found at station 1 and the lowest number of taxa was found at station 4. Land utilization around station 1 included production forest, plantation and nondensely populated housing, while land utilization in station 4 was plantation, livestock and densely populated housing. Community-generated activities can affect water conditions in rice fields, causing some macroinvertebrates to not survive and suffer population decline [16].

\section{Relative Density of Macroinvertebrates}

The lowest relative density at station 1 was Coegnagriodae family, which was found as much as $1.51 \%$, while the highest relative density was Physidae family, which was found as much as $36.36 \%$. Ecologically, this odonate order breeds in aquatic environments, and its life cycle is in the water. Odonate also breeds in shaded water and water which has moderate sunlight intensities [17]. The lowest relative density at station 2 was Unionidae family, which was found as much as $1.13 \%$, while the highest relative density was Baetidae family, which was found as much as 35.22\%.

The lowest relative density at station 3 was Gomphiidae family, which was found as much as $1.73 \%$, and the highest relative density was Physidae family, which was found as much as $60.87 \%$. Physidae was also found in station 3 and 4, but the number of densities found was different. Habitats of the Physidae group are commonly found in ponds, lakes, and rivers with a calm stream, but occasionally, it is also found in rapid-streamed waters [18]. The finding of Physidae in large enough quantities means that it can still be found in waters with moderate current velocities.

\section{Analysis of BMWP-ASPT Index}

The BMWP index modification analysis of macroinvertebrate classification on tertiary channel can be seen in (Table 3).

Table 3. ASPT score of each station

\begin{tabular}{|c|c|c|c|}
\hline No & Station & ASPT & $\begin{array}{c}\text { Category of } \\
\text { condition }\end{array}$ \\
\hline 1 & Station 1 & 4.20 & Plenty / Poor \\
\hline 2 & Station 2 & 3.55 & Bad \\
\hline 3 & Station 3 & 4.12 & Plenty / Poor \\
\hline 4 & Station 4 & 3.87 & Bad \\
\hline
\end{tabular}

Source: Result of Analysis 2018

ASPT value obtained as bioindicator to the quality of tertiary waters used the scoring modification of BMWP (Biological Monitoring Working Party), i.e. Bad and Plenty/Poor. The low value of BMWP-ASPT was due to the degradation of physical habitat, household waste, and agricultural seasonal activities [15]. The low ASPT value was due to the discovery of the Lumbricullidae, Tanypodinae, Richardsonianidae, and Chirinomidae. These families had fairly low aquatic values. Therefore, it can survive despite being in a bad water condition. Poor water quality in the tertiary channel was also caused 
by human activities in direct contact with the sampling site. The worse the condition of the waters, it will have an impact on the loss of intolerant macroinvertebrates.

\section{Physical and Chemical Parameters}

Physical and chemical parameters are important parameters to support macroinvertebrate's life. Water quality analysis results can be seen in Table 4.

Table 4. Physical and chemical indicators of each station

\begin{tabular}{llllll}
\hline \multirow{2}{*}{ St. } & pH & Temp. & DO & BOD & COD \\
\hline 1 & 6.8 & $28^{\circ} \mathrm{C}$ & 4.1 & 6.13 & 30.12 \\
2 & 6.5 & $27.7^{\circ} \mathrm{C}$ & 4.7 & 7.52 & 32.04 \\
3 & 6.3 & $27.3^{\circ} \mathrm{C}$ & 4.2 & 6.31 & 31.13 \\
4 & 6.4 & $27.1^{\circ} \mathrm{C}$ & 3.1 & 9.02 & 35.25 \\
\hline
\end{tabular}

Source: Result of Analysis 2018

Water quality on physical and chemical parameters was due to marine degradation of habitat, household waste, occupants and seasonal agricultural activities [19]. Based on the results of environmental parameters test, it was obtained that temperature was still quite normal, rising temperatures on the water surface was caused by the high intensity of sunlight [20]. The measured $\mathrm{pH}$ measurements ranged from 6.3 to 6.8 , the fluctuations generated by the high or low value of $\mathrm{pH}$ was caused by household activities and the use of agricultural materials, both organic and inorganic. From parameter testing, it obtained DO value, which was low i.e. 3.1 - $4.7 \mathrm{mg} / \mathrm{L}$, low DO value caused $B O D$ value to increase. BOD value is the value that will show the amount of oxygen required by the aerobic bacteria to decompose the organic material.

The high value of COD at each station indicated that an increase in organic matter was contained in water. The high content of COD in water was influenced by the high BOD value caused by the high organic and inorganic materials entering the water bodies and then degraded by microbes, which then would accumulate with water.

\section{CONCLUSION}

Poor water quality at all stations occured due to the discovery of water macroinvertebrates that were tolerant of poor water quality. From the sampling results, 17 families were found, macroinvertebrate communities found was classified in macroinvertebrates which were tolerant to contaminated water.

Based on the calculation of the BMWP-ASPT index, all stations were classified in "quite-poor" and "bad" water quality. The low ASPT value was due to the discovery of Tanypodinae, Lumbriculidae, Richardsonianidae and Chironomidae families.

These results were reinforced by physical and chemical parameter testing. The low DO value caused the BOD value to increase affecting the increase of COD value. Increased COD values were caused by the inclusion of organic and inorganic materials into water bodies, thus causing the loss of intolerant macroinvertebrates.

Further research is expected to compare several parameters in two seasons: summer and rainy season, educating the public about the importance of maintaining continuity to water quality.

\section{ACKNOWLEDGEMENTS}

We are very grateful to Laboratory Assistant of Faculty of Science of Cokroaminoto Palopo University who are willing to assist the process of taking and testing water samples and identification process. We also offer our gratitude to the advisors who always take time during the process of research report assistance.

\section{REFERENCES}

[1]. Haynes, H.B.N. 1977. Adult and Nymphs of British Stoneflis (Plecoptera).3th edition. Freshwater Biological Association.

[2]. Peraturan Pemerintah Republik Indonesia Nomor 121 Tahun 2015 tentang Pengusahaan Sumber Daya Air

[3]. Rahayu. S. Widodo. R. H., Noordwijk. M. V., Suryadi. I., Verbist. B. 2009. Monitoring Air di DAS. Worl Agroforestry Centre. Bogor. hal. 104

[4]. Cottam T. 1969. Research for Establishment of Water Quality Criteria for Aquatic Life. Reprint Transac of the 2nd Seminar on Biology, April 20-24, Ohio.

[5]. Callisto, M.; Moretti, M. \& Goulart, M.D.C. 2001. Macroinvertebrados bentonicos como ferramenta para avaliar a saude de riachos. Revista Brasileira de Recursos Hidricos, 6(1): 7182.

[6]. Widianto, Joko. Sulistiyarsi, Ani. 2016. "Biomonitoring Kualitas Air Sungai Madiun Dengan Bioindkator Makroinvertebrata". Jurnal LPPM Vol. 4 No. 1 Januari 2016

[7]. Sandi, M., Apriliawati. Arthana, I Wayan. Sari, A., Hermawati Waskita. "Bioassesment dan 
Kualitas Air Daerah Aliran Sungai Legundi Probolinggo Jawa Timur". Journal of Marine Aquatic Sciences Vol. 3 No. 2 Agustus 2017

[8]. Mariantika, Lina. Retnaningdyah, Catur. 2014. "Perubahan Struktur Komunitas Makroinvertebrata Bentos Akibat Aktivitas Manusia di Saluran Mata Air Sumber Awan Kecamatan Singosari Kabupaten Malang". Jurnal Biotropika Vol. 2 No. 5

[9]. Wardhana, W. 1999. Perubahan Lingkungan Perairan dan Pengaruhnya Terhadap Biota Akuatik. Jurusan Biologi FMIPA UI. Jakarta

[10]. Cranston, P.S., P. Fairweather \& G. Clark. 1996. Biological Indicators of Water Quality in Indicators of Cacthment Health: A Technical. Csiro. Melbourne.

[11]. Spelman, F. R, \& Drinan, J. E. (2001). Stream Ecology and Self Purification. Pennsylvinia: Technomic Publising Company, Inc.

[12]. [Haq, N. F. A., Laili, S., \& Syauqi, A. (2015). Uji Kualitas Perairan dan Pengaruhnya terhadap Indeks Keanekaragaman Makrofauna di DAS Janjang Madura. BIOSAINTROPIS (BIOSCIENCETROPIC), 1(1). Retrieved from http://biosaintropis.unisma.ac.id/index.php/bi osaintropis/article/view/39/23

[13] Metcalfe, J. L. (1989). Biological water quality Assessment of Running Waters Based on Macroinvertebrate Communities: History and present status in europe. Environmental Pollution, 60(1-2), 101-139. https://doi.org/10.1515/biolog-2016-0005.

[13]. Galbrand, C.; I. G. Lemieux; A. E. Ghaly; R. Cote; and M. Verma. 2007. Assessment of Constructed Wetland Biological Integrity Using Aquatic Macroinvertebrate. Online Journal of Biological Sciences 7 (2): 52-65. ISSN 16084217. Science Publications. Dalhousie University. Canada.

[14]. Suwignyo, S. B. Widigdo, Y. Wardianto dan M. Krisanti. 2005. Avertebrata Air Jilid 2. Jakarta: Penebar Swadaya

[15]. Rahadi WS, Feriwibisono B, Nugrahani MP. 2013. Naga Terbang Wendit, Keanekaragaman Capung Perairan Wendit, Malang, Jawa Timur. Indonesia Dragonfly Society, Malang.

[16]. Thorp, J. H., Rogers, D. C., \& Dimmick, W. W. (2014). Thorp and Covich's Freshwater Invertebrates: Ecology and General Biology: Fourth Edition. Thorp and Covich's Freshwater Invertebrates: Ecology and General Biology: Fourth Edition (Vol. https://doi.org/10.1016/C2010-0-65590-8
[17]. Arslan, N., Salur, A., Kalyoncu, H., Mercan, D., Barisik, B., \& Odabasi, D. A. (2016). The use of BMWP and ASPT indices for evaluation of water quality according to macroinvertebrates in Kucuk Menderes River (Turkey). In Biologia (Poland) (Vol. 71, pp. 49-57). https://doi.org/10.1515/biolog-2016-0005

[18]. Hartoto, D.I. dan E. Mulyana. 1996. Hubungan Parameter Kualitas Air dengan Struktur Ikhtiofauna Perairan Darat Pulau Siberut. Oseanologi dan Limnologi di Indonesia No. 29: 41- 55.

[19]. Effendi, H. 2003. Telaah Kualitas Air bagi Pengelolaan Sumber Daya dan Lingkungan Perairan. Kanisius. Yogyakarta. 